\title{
HELLP syndrome and its implications on maternal and perinatal outcome
}

\author{
Amrit Pal Kaur, Navdeep Kaur*, S. P. S. Dhillon
}

Department of Obstetrics and Gynecology, Government Medical College, Amritsar, Punjab, India

Received: 29 December 2017

Accepted: 03 January 2018

*Correspondence:

Dr. Navdeep Kaur,

E-mail: nvdpkaur.15@gmail.com

Copyright: () the author(s), publisher and licensee Medip Academy. This is an open-access article distributed under the terms of the Creative Commons Attribution Non-Commercial License, which permits unrestricted non-commercial use, distribution, and reproduction in any medium, provided the original work is properly cited.

\begin{abstract}
Background: The HELLP syndrome is characterized by hemolysis $(\mathrm{H})$, elevated liver enzymes (EL) and low platelet count (LP). This syndrome in general complicates $0.2-0.6 \%$ of all pregnancies but its incidence increases to $4-12 \%$ in severe preeclampsia. In about $15 \%$ cases, HELLP syndrome presents without definitive criteria for preeclampsia (atypical preeclampsia). This present study will throw light on incidence, clinical and biochemical profile of patients with HELLP syndrome and maternal and perinatal outcome.

Methods: A prospective study was conducted in the department of Obstetrics and Gynecology, Bebe Nanki Mother and Child Care Centre, Amritsar, India from January 2016 to August 2017 after approval from institutional ethics committee.

Results: In the present study, total 2949 antenatal admissions were there during the course of study. Out of these patients, 352 patients had preeclampsia-eclampsia (11.93\%). Out of these 352 patients, 71 complicated with HELLP syndrome (20.17\%). 17.9\% had partial HELLP and 2.3\% had complete HELLP syndrome. 30.16\% had only EL, $31.75 \%$ had only LP, $87.3 \%$ had elevated LDH (depicted hemolysis). 4.76\% had both EL and LP, 30.16\% had both EL and elevated LDH, $20.63 \%$ had both LP and elevated LDH levels. Majority of the patients presented after 36 weeks of gestation. Only 5 patients had HELLP syndrome in the postpartum period. Among partial HELLP patients, $59.02 \%$ delivered vaginally and $40.98 \%$ delivered by LSCS and among complete HELLP patients $28.6 \%$ delivered vaginally and $71.4 \%$ delivered by LSCS. Perinatal mortality rate was $43.7 \%$. Severe maternal complications such as PPH, DIC, abruptio placentae, pulmonary edema and renal failure were seen high among HELLP patients.

Conclusions: As the incidence is very high, one must be aware of its clinical and laboratory findings so that early diagnosis and treatment can be initiated. Close surveillance of the mother should be continued even after delivery.
\end{abstract}

Keywords: EL, HELLP syndrome, LP, LDH, Preeclampsia

\section{INTRODUCTION}

HELLP syndrome is one of the serious complication of preeclampsia with high risk for the mother and the fetus and is characterized by hemolysis, elevated liver enzymes and low platelet count. It was first suggested by Weinstein in 1982. ${ }^{1}$ This syndrome in general complicates $0.2-0.6 \%$ of all pregnancies but its incidence increases to $4-12 \%$ in severe preeclampsia. In about $70 \%$ of the cases, the HELLP syndrome develops before delivery with a peak frequency between $27^{\text {th }}$ and $37^{\text {th }}$ gestational weeks; $10 \%$ occur before the $27^{\text {th }}$ week and $20 \%$ beyond $37^{\text {th }}$ gestational week. ${ }^{2}$ In the postpartum period the HELLP syndrome usually develops within 48 hours in women with hypertensive disorder of pregnancy. Although variable, the onset of the HELLP syndrome is usually rapid. ${ }^{3}$ Majority of women with this syndrome have had hypertension and proteinuria, which may be 
absent in $10-20 \%$ of the cases. ${ }^{4}$ Excessive weight gain and generalized edema precede the syndrome in more than $50 \%$ of the cases. The presentation of patients with HELLP syndrome is variable. The patients may have symptoms from flu like illness to gastrointestinal hemorrhage. $^{5} 90 \%$ of patients experience malaise, fatigue, and nonspecific complaints for a few days seeking medical evaluation. The ominous symptom of epigastric or right upper quadrant pain is present only in half to two-thirds of patients. ${ }^{6,7}$

There are two major classifications for diagnosing HELLP syndrome i.e. Tennesse classification and Mississippi classification (Class 1, 2 and 3). Diagnosis of the complete HELLP syndrome requires the presence of all 3 major components while partial or incomplete HELLP syndrome consists of only 1 or 2 elements of the triad.

Diagnosis of HELLP syndrome is an indication for immediate delivery if pregnancy is $\geq 34$ weeks or at any gestational age if pulmonary edema, placenta abruption, non-reassuring fetal status and uncontrollable hypertension is present. All other cases require administration of magnesium sulfate, steroids and delivery within 24 hours after the second steroid dose. ${ }^{8}$ Maternal and fetal condition, gestational age, bishops score, inducibility of the cervix are few factors which helps in deciding over the mode of delivery.

\section{METHODS}

This prospective study was conducted in the department of Obstetrics and Gynecology at Bebe Nanki Mother and Child Care Centre, Government Medical College, Amritsar from January 2016 to August 2017 after approval of institutional ethics committee.

Informed consent was taken from each patient prior to the start of the study. Total numbers of antenatal admissions during the course of study were recorded. The mothers suffering from hypertensive disorders of pregnancy were selected. Further, these patients were classified into different classes of hypertensive disorders of pregnancy. The patients who suffered from preeclampsia -eclampsia were studied and looked for the complication of HELLP syndrome.

Number of cases and control

1. Group A (study group): included 200 patients suffering from hypertensive disorders of pregnancy with preeclampsia and eclampsia. It was further subdivided into the following subgroups:

- Subgroup A: Mild preeclampsia-patients with systolic blood pressure less than $160 \mathrm{~mm} \mathrm{Hg}$ and diastolic blood pressure less than $110 \mathrm{~mm} \mathrm{Hg}$.

- Subgroup B: Severe preeclampsia-patients with systolic blood pressure $\geq 160 \mathrm{~mm} \mathrm{Hg}$ and diastolic blood pressure $\geq 110 \mathrm{~mm} \mathrm{Hg}$.
- Subgroup C: Eclampsia

- Atypical preeclampsia

2. Group B (control group): included two hundred normotensive antenatal patients.

Women were subjected to detailed history taking, clinical examination, presence of albumin in urine, hemoglobin, platelet count and biochemical investigations. Labour was monitored and mode of delivery was noted. Patients were subjected to repeat biochemical investigations; hemoglobin level and platelet count in the postpartum period after 48 hours. Preeclampsia and eclampsia patients complicated with HELLP syndrome with its implications on maternal and perinatal outcome were noted.

Maternal outcome was measured in terms of age of mother, parity, socioeconomic status, period of gestation, severity of preeclampsia, eclampsia, class of HELLP syndrome, mode of delivery, need for blood products, maternal complications like pulmonary edema, acute renal failure, abruption placenta, disseminated intravascular coagulation, postpartum haemorrhage and maternal mortality.

Perinatal outcome was measured in terms of prematurity, dysmaturity, intrauterine fetal demise, birth asphyxia, APGAR score, neonatal jaundice, hypoglycemia, hypocalcemia, sepsis, NICU admission and early neonatal death. Baby was followed upto 7 days after birth.

\section{RESULTS}

There were 2949 antenatal admissions during the course of study. Out of these 2949, 352 patients had preeclampsia /eclampsia with incidence of $11.93 \%$. Out of these 352 patients, 71 had complication of HELLP syndrome with incidence of $20.17 \%$ among preeclampsia/eclampsia patients. 8 patients $(2.3 \%)$ had all the features of HELLP syndrome and 63 (17.9\%) had partial HELLP syndrome.

Table 1: Clinical profile of the patients with HELLP syndrome.

\begin{tabular}{|c|c|c|c|c|}
\hline Symptoms & \multicolumn{2}{|c|}{$\begin{array}{l}\text { Partial HELLP } \\
(n=63)\end{array}$} & \multicolumn{2}{|c|}{$\begin{array}{l}\text { Complete } \\
\text { HELLP }(n=8)\end{array}$} \\
\hline Severe headache & 30 & $47.6 \%$ & 3 & $37.5 \%$ \\
\hline Vomiting & 18 & $28.57 \%$ & 3 & $37.5 \%$ \\
\hline Epigastric pain & 8 & $12.7 \%$ & 5 & $62.5 \%$ \\
\hline $\begin{array}{l}\text { Visual } \\
\text { disturbances }\end{array}$ & 27 & $42.85 \%$ & 4 & $50 \%$ \\
\hline
\end{tabular}

Mean age of all the patients with HELLP syndrome was 25.33 \pm 5.00 years. Among the partial HELLP syndrome, majority of the patients had severe preeclampsia (33.33\%), 25.4\% had atypical preeclampsia with no proteinuria, $22.22 \%$ were with eclampsia and $19.05 \%$ had mild preeclampsia. 
Table 2: Laboratory investigations at time of admission and after 48 hours of delivery.

\begin{tabular}{|lllll|}
\hline & Partial HILLLP & & \multicolumn{1}{c|}{ Complete HELLP } \\
\hline & Anteparum & Postpartum & Antepartum & Postpartum \\
\hline Mean Hb (gm/dl) & $8.19 \pm 1.02$ & $8.56 \pm 1.03$ & $5.97 \pm 1.07$ & $8.03 \pm 0.99$ \\
\hline Mean Platelet count (lac/cumm) & $1.58 \pm 0.54$ & $1.8 \pm 0.47$ & $0.66 \pm 0.40$ & $0.77 \pm 0.24$ \\
\hline Mean S.bilirubin (mg/dl) & $1.43 \pm 0.759$ & $0.953 \pm 0.386$ & $2.48 \pm 1.40$ & $2.16 \pm 1.97$ \\
\hline Mean SGOT (IU/L) & $58.93 \pm 44.00$ & $50.65 \pm 24.09$ & $93.62 \pm 31.81$ & $74.16 \pm 29.97$ \\
\hline Mean SGPT (IU/L) & $60.10 \pm 41.83$ & $49.58 \pm 24.58$ & $97.87 \pm 39.14$ & $67.33 \pm 27.69$ \\
\hline Mean LDH (U/L) & $832.17 \pm 249.81$ & $686.44 \pm 238.726$ & $1798 \pm 1196.25$ & $1306.33 \pm 296.94$ \\
\hline
\end{tabular}

Among complete HELLP patients, 4 (50\%) had severe preeclampsia, $2(25 \%)$ had atypical preeclampsia, 1 patient $(12.5 \%)$ had eclampsia and 1 patient $(12.5 \%)$ was with mild preeclampsia. $30.16 \%$ patients of partial HELLP had only elevated liver transaminases, $31.75 \%$ only low platelet count, $87.3 \%$ had elevated LDH levels (indicative of hemolysis), $4.76 \%$ had both elevated liver enzymes and low platelet count, $30.16 \%$ had both elevated liver enzymes and LDH, 20.63\% had both elevated LDH and low platelet count. Majority of the patients were primigravida i.e. $63.49 \%$ in partial HELLP and $62.5 \%$ in complete HELLP syndrome. In group 2, primigravidae and multigravidae were $50 \%$ each $(\mathrm{p}=0.05)$.

Mean gestational age of all the patients with HELLP syndrome was $36.33 \pm 3.62$ weeks. Only 5 patients presented with partial HELLP syndrome after delivery within 48 hours. Mean systolic and diastolic blood pressure of all the patients with HELLP syndrome was $163.21 \pm 18.57 \mathrm{mmHg}$ and $109.32 \pm 9.16 \mathrm{mmHg}$ respectively.

\section{Mode of delivery}

Among the patients of partial HELLP, $58.73 \%$ had vaginal delivery and $41.27 \%$ had cesarean section.

Table 3: Perinatal complications.

\begin{tabular}{|lllllll|} 
& $\begin{array}{l}\text { Partial } \\
\text { HELLP } \\
(\mathrm{n}=63)\end{array}$ & $\begin{array}{l}\text { Complete } \\
\text { HIELCP } \\
(\mathrm{n}=8)\end{array}$ & $\begin{array}{l}\text { Group } 2 \\
(\mathrm{n}=200)\end{array}$ \\
\hline $\begin{array}{l}\text { Prematurity } \\
\text { Respiratory }\end{array}$ & 15 & $23.81 \%$ & 4 & $50 \%$ & 12 & $6 \%$ \\
distress & 19 & $30.16 \%$ & 4 & $50 \%$ & 12 & $6 \%$ \\
\hline IUGR & 22 & $34.92 \%$ & 3 & $37.5 \%$ & 2 & $1 \%$ \\
\hline IUD & 20 & $31.75 \%$ & 3 & $37.5 \%$ & 6 & $3 \%$ \\
\hline NICU admission & 15 & $23.81 \%$ & 3 & $37.5 \%$ & 2 & $1 \%$ \\
$\begin{array}{l}\text { Early neonatal } \\
\text { death }\end{array}$ & 6 & $9.5 \%$ & 2 & $25 \%$ & 2 & $1 \%$ \\
\hline
\end{tabular}

Among complete HELLP, 25\% had vaginal delivery and $75 \%$ underwent cesarean section. Among group 2, 68.5\% had vaginal delivery and $31.5 \%$ underwent cesarean section $(\mathrm{p}=0.04)$. Perinatal mortality rate among all the HELLP syndrome patients was $43.7 \%$.

Table 4: Maternal complications.

\begin{tabular}{|c|c|c|c|c|}
\hline & $\begin{array}{l}\text { Partial } \\
\text { HELLP } \\
(n=63)\end{array}$ & & $\begin{array}{l}\text { plete } \\
\text { LP }\end{array}$ & $\begin{array}{l}\text { Group } 2 \\
(n=200)\end{array}$ \\
\hline PPH & $6 \quad 9.52 \%$ & 2 & $25 \%$ & $3.5 \%$ \\
\hline DIC & $1 \quad 1.59 \%$ & 3 & $37.5 \%$ & $0 \%$ \\
\hline $\begin{array}{l}\text { Abruptio } \\
\text { placentae }\end{array}$ & $\begin{array}{ll}1 & 15.8 \%\end{array}$ & 2 & $25 \%$ & $0 \%$ \\
\hline $\begin{array}{l}\text { Pulmonary } \\
\text { edema }\end{array}$ & $7.94 \%$ & 2 & $25 \%$ & $0 \quad 0 \%$ \\
\hline Renal shut down & $4 \quad 6.35 \%$ & 4 & $50 \%$ & $0 \%$ \\
\hline Maternal death & $8 \quad 12.7 \%$ & 6 & $75 \%$ & $0 \quad 0 \%$ \\
\hline
\end{tabular}

Majority of the patients had complications associated with HELLP syndrome. Out of 8 patients of complete HELLP, 6 (75\%) patients died. Among partial HELLP patients, 8 maternal deaths were seen $(12.7 \%)$.

\section{DISCUSSION}

It has been widely accepted that standard antenatal care has immense values in reducing the incidence of HELLP syndrome by early detection of preeclampsia and its prompt management. HELLP syndrome was originally described by Pritchard et al in and the acronym was coined by Weinstein. ${ }^{1,9}$ HELLP syndrome is a poorly understood pregnancy related condition with a rapid onset and is typically seen in patients with severe preeclampsia, although it can occur in the absence of preeclampsia in $10 \%$ of the cases (atypical presentation).

Mean maternal age in our study was $25.36 \pm 5.00$ years comparable with the study conducted by Bang NO et al i.e.27.31 \pm 5.0 years. ${ }^{10}$ Majority of the patients in the present study were primigravid, $63.64 \%$ in complete HELLP and $66.55 \%$ in partial HELLP syndrome. The results were comparable with study by Boopathi A and Kushtagi $\mathrm{P}$ et al in which $60.7 \%$ patients with HELLP syndrome were primigravida. ${ }^{11}$

In the present study the incidence of HELLP syndrome was $20.17 \%$ among the preeclampsia/eclampsia patients. 
The result was comparable with the study by Rose $\mathrm{J}$ et al i.e. $22.87 \% .^{12}$ Mean gestational age among partial HELLP syndrome patients was $36.34 \pm 3.75$ weeks and among complete HELLP patients was $36.32 \pm 2.60$ weeks and comparable with the study conducted by Kaur AP et al i.e. $36.06 \pm 3.50$ weeks in partial HELLP and $35.00 \pm 4.3589$ weeks in complete HELLP syndrome. ${ }^{13}$ Mean systolic and diastolic blood pressure in all the patients with HELLP syndrome was $163.21 \pm 18.5 \mathrm{mmHg}$ and $109.32 \pm 9.16 \mathrm{mmHg}$ comparable with mean systolic and diastolic blood pressure in the study by Chawla $\mathrm{S}$ et al i.e. $166 \pm 18.65$ and $110.5 \pm 12.7 \mathrm{mmHg}$, respectively. ${ }^{14}$ The mean platelet count in the patients with complete HELLP in the present study was $0.668 \pm 0.40 \mathrm{lacs} / \mathrm{cumm}$ comparable with the study by Osmanagaoglu MA et al i.e. $62,676 \pm 38,333.37 / \mathrm{cumm}^{15}$ Mean LDH levels in the present study at time of admission was $832.17 \pm 249.81$ U/L in partial HELLP patients and 1798.25 $\pm 1196.25 \mathrm{U} / \mathrm{L}$ in complete HELLP patients. In the study by Rakshit A et al, mean LDH levels in partial HELLP was 996.1 \pm 246.3 U/L and in complete HELLP was 1018.5 \pm 383.7 U/L. ${ }^{16}$

In the present study, $30.16 \%$ had only elevated liver enzymes, $33.33 \%$ had only low platelet count. Kaur AP et al conducted a study in which only elevated liver enzymes was seen in $67.5 \%$ of partial HELLP patients (higher than our study) and $24.3 \%$ had only low platelet count (slightly lower than our study). ${ }^{13}$

\section{Maternal and perinatal outcome}

In the present study, among partial HELLP patients, $58.73 \%$ delivered vaginally and $41.27 \%$ underwent cesarean section and among complete HELLP patients, $25 \%$ had vaginal delivery and $75 \%$ had cesarean section. The results were comparable with study by Rakshit A et al i.e. VD in $27.27 \%$ and LSCS in $72.72 \%$ among complete HELLP patients. $^{16}$ Perinatal mortality rate among all the patients of HELLP syndrome was $43.7 \%$ comparable with the study by Rose J et al i.e. $42.2 \% .^{12}$ In the present study, $22.22 \%$ patients with partial HELLP had eclampsia and $12.5 \%$ patients of complete HELLP had eclampsia and this was comparable with study by Bang NO et al in which $23 \%$ had eclampsia with HELLP syndrome. Total 14 maternal deaths were seen out of 71 patients with HELLP syndrome $(19.7 \%)$ lower than study by Tiwari $\mathrm{P}$ et al i.e. $37.5 \% .^{17}$

\section{CONCLUSION}

HELLP syndrome complicates women with preeclampsia. Pregnancies complicated with HELLP syndrome are unpredictable and are predilected with worst prognosis. As the incidence of HELLP syndrome is very high, one must be aware of this syndrome as well as its clinical and laboratory findings, so that proper diagnosis can be made, and therapy can be initiated as early as possible. Adverse maternal and perinatal outcomes stresses upon the need for early ANC registration, regular antenatal follow up and monitoring of clinical symptoms and laboratory parameters.

Funding: No funding sources

Conflict of interest: None declared

Ethical approval: The study was approved by the Institutional Ethics Committee

\section{REFERENCES}

1. Weinstein L. Syndrome of hemolysis, elevated liver enzymes and low platelet count; a severe consequence of hypertension in pregnancy. Am $\mathrm{J}$ Obstet Gynecol. 1982;142(2):159-67.

2. Magann EF, Martin JN Jr: Twelve steps to optimal management of HELLP syndrome. Clin Obstet Gynecol. 1999;42:532-50.

3. Martin JN Jr, Rose CH, Briery CM. Understanding and managing HELLP syndrome: the integral role of aggressive glucocorticoids for mother and child. Am J Obstet Gynecol. 2006;195:914-34.

4. Sibai BM. Diagnosis, controversies, and management of the syndrome of hemolysis, elevated liver enzymes, and low platelet count. Obstet Gynecol. 2004;103:981-91.

5. Geary M. The HELLP Syndrome. Br J Obstet Gynecol. 1997;104:887-91.

6. Sibai BM, Taslimi MW, El-Nazer A, Amon E, Mabie BG, Regan GM. Maternal- perinatal outcome associated with the syndrome of hemolysis, elevated liver enzymes and low platelets in severe preeclampsia-eclampsia. Am J Obstet Gynecol. 1986;155(3):501-8.

7. Sibai BM. The HELLP syndrome (hemolysis, elevated liver enzymes, and low platelets): much ado about nothing? Am J Obstet Gynecol. 1990;162:3116.

8. Bansal V, Damania KR. Hypertensive Disorders in Pregnancy. In: Bhide A, Arulkumaran S, Damania K, Daftary SN. Arias' Practical guide to high-risk pregnancy and delivery. 4th ed. Elsevier;2015:185232.

9. Pritchard JA, Weisman Jr R, Ratnoff OD, Vosburgh GJ. Intravascular hemolysis, thrombocytopenia and other hematologic abnormalities associated with severe toxemia of pregnancy. $\mathrm{N}$ Engl $\mathrm{J}$ Med. 1954;250:89-98.

10. Bang NO, Satia MN, Poonia S. Obstetric and neonatal outcome in pregnancies complicated by hemolysis elevated liver enzymes low platelet count syndrome at a tertiary care centre in India. Int $\mathbf{J}$ Reprod Contracept Obstet Gynecol. 2017;5(7):240712.

11. Boopathi A, Kushtagi P. HELLP syndrome in a Government District Hospital on the west coast in South India. Int J Biomed Res. 2014;5(7):439-42.

12. Rose J, Arrm M, Dominic M, Mohammad AS. Maternal and perinatal outcome associated with the syndrome of hemolysis, elevated liver enzymes and 
low platelets in preeclampsia/eclampsia. J Obstet Gynecol Ind. 2004;54(2):147-50.

13. Kaur AP, Saini AS, Dhillon SPS. HELLP syndrome associated with moderate to severe preeclampsiaeclampsia. J Obstet Gynecol India.2003;53(2):165-9.

14. Chawla S, Marwaha A, Agarwal R. HELLP OR help: a real challenge. J Obstet Gynecol India 2015;65(3):172-5.

15. Osmanagaoglu MA, Osmanagaoglu S, Ulusoy $\mathrm{H}$. Bozkaya H. Maternal outcome in HELLP syndrome requiring intensive care management in a Turkish hospital. Sao Paulo Med J. 2006;124:85-9.

16. Rakshit A, Lahiri S, Biswas SC, Dey R, Roy BR, Saha MM. A study to detect HELLP syndrome and partial HELLP syndrome among preeclamptic mothers and their impact on fetomaternal outcome. Al Ameen J Med Sci. 2014;7(1):20-5.

17. Tiwari P, Bhalavi S, Nayak S, Tiwari R. A study of HELLP syndrome among cases of pre-eclampsia and eclampsia: incidence and correlation of laboratory parameters. Open Access Library J. 2015;2(9):1.

Cite this article as: Kaur AP, Kaur N, Dhillon SPS. HELLP syndrome and its implications on maternal and perinatal outcome. Int J Reprod Contracept Obstet Gynecol 2018;7:1007-11. 